\title{
Accumulation of TDP-43 and $\alpha$-actin in an amyotrophic lateral sclerosis patient with the K17I $A N G$ mutation
}

Danielle Seilhean, Cécile Cazeneuve, Valérie Thuriès, Odile Russaouen, Stéphanie Millecamps, François Salachas, Vincent Meininger, Eric LeGuern, Charles Duyckaerts. 
D. Seilhean (corresponding author), C. Duyckaerts,

UPMC Université Paris 06, AP-HP, Assistance Publique Hôpitaux de Paris, Groupe Hospitalier Pitié-Salpêtrière, Département de Neuropathologie, INSERM UMR-S 546 (DS) and UMR-S 679 (CD), 47-83 boulevard de l'Hôpital , 75651 Paris cedex 13, France

Tel: 33-1-42 1618 81; Fax: 33-1-42 1618 99; Email: danielle.seilhean@psl.aphp.fr

C. Cazeneuve,

AP-HP, Assistance Publique Hôpitaux de Paris, Groupe Hospitalier Pitié-Salpêtrière, Département de Génétique et Cytogénétique, U.F. de Neurogénétique Moléculaire et Cellulaire, Paris, France

\section{Thuriès,}

AP-HP, Assistance Publique Hôpitaux de Paris, Groupe Hospitalier Pitié-Salpêtrière, Département de Neuropathologie, Paris, France

O. Russaouen,

AP-HP, Assistance Publique Hôpitaux de Paris, Groupe Hospitalier Pitié-Salpêtrière, Département de Génétique et Cytogénétique, U.F. de Neurogénétique Moléculaire et Cellulaire, Paris, France.

\section{S. Millecamps,}

Laboratoire de Génétique Moléculaire de la Neurotransmission et des Processus Neurodégénératifs, CNRS UMR 7091, UPMC Université Paris 06, Groupe Hospitalier Pitié-Salpêtrière, Paris, France.

F. Salachas,

AP-HP, Assistance Publique Hôpitaux de Paris, Groupe Hospitalier Pitié-Salpêtrière, Fédération de Neurologie, Paris, France.

\section{Meininger,}

UPMC Université Paris 06, AP-HP, Assistance Publique Hôpitaux de Paris, Groupe Hospitalier Pitié-Salpêtrière, Fédération de Neurologie, Paris, France.

\section{E. LeGuern,}

UPMC Université Paris 06, INSERM, UMR-S 679 Neurologie \& Thérapeutique Expérimentale, AP-HP, Assistance Publique Hôpitaux de Paris, Groupe Hospitalier Pitié-Salpêtrière, Département de Génétique et Cytogénétique, U.F. de Neurogénétique Moléculaire et Cellulaire, Paris, France 
Key words : Neuropathology, motor neuron disease, ALS, hippocampus, neuronal intranuclear inclusions, actin, angiogenin, actinin, TDP-43, steatosis

\section{Abstract.}

A K17I mutation in the $A N G$ gene encoding angiogenin has been identified in a case that we previously published as ALS with neuronal intranuclear protein inclusions (Seilhean et al., Acta Neuropathol. 2004). These inclusions were immunoreactive for smooth muscle $\alpha$-actin but not for angiogenin. Moreover, they were not labeled by anti-TDP-43 antibodies, while numerous cytoplasmic inclusions immunoreactive for ubiquitin, p62 and TDP-43 were detected in both oligodendrocytes and neurons in various regions of the central nervous system. In addition, the expression of smooth muscle $\alpha$-actin was increased in the liver in which a severe steatosis was observed. This is the first neuropathological description of a case with an $A N G$ mutation. Angiogenin is known to interact with actin. Like other proteins involved in ALS pathogenesis, such as senataxin, TDP-43 and FUS/TLS, it plays a role in RNA maturation. 


\section{Introduction}

Amyotrophic lateral sclerosis (ALS) is a fatal neurodegenerative disorder causing progressive muscle weakness due to the loss of upper and lower motor neurons. About $10 \%$ of ALS cases are familial; of these $20 \%$ are related to mutations of the $\mathrm{Cu} / \mathrm{Zn}$ superoxide dismutase1 (SOD1) gene encoding an antioxidant enzyme [50]. Other proteins implicated in the pathogenesis of ALS are the vesicle-trafficking protein VAPB [37, 44], the guanine-nucleotide exchange factor alsin [67], senataxin that is putatively involved in DNA repair and RNA processing [6], the $43 \mathrm{kDa}$ TAR-DNA binding protein (TARDBP or TDP-43) [8, 16, 30, 52, 57, 60, 68] and recently another DNA/RNA-binding protein FUS/TLS [35, 61]. A relationship between angiogenesis and the development of ALS had been previously suggested since chronic vascular insufficiency and, possibly, insufficient VEGF-dependent neuroprotection led to motor neuron degeneration (MND) in mice [45]. This hypothesis was confirmed by the identification of mutations of $A N G$, encoding angiogenin, an inducer of neovascularization, in some ALS patients $[14,17,18]$.

We previously described the case of a 46 year old woman with a rapidly progressive form of ALS which required mechanical ventilation nine months after onset [53]. The patient had no known familial history of ALS. She died after a four year course. Neuropathology showed severe degeneration of the spinal cord, sparing only the posterior columns (Fig. 1a-b), associated with neuronal loss in the substantia nigra and neuronal intranuclear inclusions (NIIs) in hippocampal pyramidal cells [53]. The NIIs were immunoreactive to ubiquitin, promyelocytic leukemia gene product (PML), ataxin-3, and proteasome 19S. They were not labeled by antibodies directed against expanded polyglutamine segments, neurofilaments, tau, synuclein, cystatin $\mathrm{C}$, and were 
not stained by ethidium bromide [53]. These results suggested an intranuclear accumulation of an unknown protein. In addition this patient presented with severe liver steatosis [12].

The principal genes responsible for the adult onset form of ALS (SOD1, ANG and TARDBP, encoding SOD1, angiogenin and TDP-43 proteins, respectively) were systematically analyzed in this patient. A K17I mutation of $A N G$ was detected. Angiogenin is a $14.1 \mathrm{kDa}$ serum protein, mainly secreted by the liver in normal conditions, that belongs to the pancreatic ribonuclease A superfamily $[15,54,63]$. First identified as an angiogenic factor in tumor-cell conditioned medium [15], angiogenin has since been implicated in various functions, including development, cell survival, and RNA maturation. Angiogenin binds to actin on the surface of endothelial cells and is internalized and transported to the nucleolus $[19,25,26]$. Once in the nucleolus, angiogenin is able to act as a stress activated ribonuclease that cleaves tRNA and inhibits protein translation [66].

Reevaluation of this case at the histological as well as immunohistochemical level including immunolabeling of angiogenin, TDP-43, p62 and known angiogenin partners or ligands in the CNS and peripheral tissues raises new questions about the pathophysiology of the disease.

\section{Methods}

\section{Case and controls}

Human tissue samples were used after consents, according to French and European regulations. Case : Samples of liver and peroneal muscle were taken at autopsy. The brain was sampled as previously described [53]. Blocks of the left hippocampus, embedded in paraffin after short (12 days) fixation in formalin were also available. Controls : A normal brain, from a patient who died from pneumonia, without known neurological disease, was used as a control for 
immunohistochemistry. Duration of the fixation was similar in the control case and in the patient. NIIs found in diseases related to a polyglutamine expansion, including Huntington disease $(\mathrm{n}=1)$ and spinocerebellar ataxia (SCA), (SCA1, n=1; SCA3, n=1; SCA7, n=2) were compared to the NIIs found in this case. A case with ALS unrelated to ANG mutation, and a case with CharcotMarie-Tooth disease were used as controls for severe muscle atrophy related to denervation. Liver samples taken in six other cases with severe steatosis were used as controls for the changes found in the liver in this case. Causes of death were acute pancreatitis in two cases, AIDS related CMV encephalitis, lung carcinoma, alcohol encephalopathy, myocardial infarct.

\section{Analysis of the ANG coding sequence by direct sequencing}

The genetic analyses were performed on a stored blood sample that had been obtained after the patient formal consent for a genetic analysis. The coding region of the SOD1 (5 exons), $T A R D B P(5$ exons) and $A N G$ (exon 1 and 2) genes were amplified in respectively 5, 6 and 3 fragments from genomic DNA, using primers containing home-made universal sequences at their 5 , end (available on request), in addition to the sequence specific to the corresponding gene. The PCR products were sequenced using the universal primer pair. Forward and reverse sequence reactions were performed with the Big Dye Terminator Cycle Sequencing Ready Reaction Kit (PE Applied Biosystems ${ }^{\circledR}$ ). Sequence products were run on an ABI 3730 automated sequencer

(PE Applied Biosystems ${ }^{\circledR}$ ). Data were analyzed with the Seqscape 2.5 software (Applied Biosystems $\left.{ }^{\circledR}\right)$.

\section{Immunohistochemistry}

After deparaffinization, the slides were immunolabeled with the antibodies listed in table 1. For most antibodies, the immunostaining was performed by an automat (Benchmark® XT 
Ventana ${ }^{\circledR}$ staining system), the slides being pre-treated by heat at $95^{\circ} \mathrm{C}$ in the $\mathrm{CC} 1$ buffer, a proprietary high $\mathrm{pH}(=8)$ retrieval buffer (Ventana Medical Systems@) (Table 1). For tau and ubiquitin immunohistochemistry, the slides were pre-treated by formic acid (FA, $80 \%$ ), for 5 to 10 minutes (Table 1). Three antibodies raised against angiogenin were tested (Table 1). For the angiogenin and p62 antibodies, the slides were pretreated by heat $(450 \mathrm{~W})$ in a microwave oven during 2 x10 min using the buffer best adapted to the $\mathrm{pH}$ found optimal for immunolabeling (Table 1).

The biotinylated secondary antibody was included in the detection kit (Ventana® Medical Systems Basic DAB Detection Kit 250-001®). The streptavidin-biotin-peroxidase complex was revealed by diamino-benzidine. A paraffin block of colic adenocarcinoma was used as positive control for angiogenin and fibulin-1, the former antibody labeling tumor cells [13] and the latter, elastic fibers [48]. Placenta was used as positive control for $\alpha$-actinin 1 , and normal striate muscle for $\alpha$-actinin 2 (Fig. 5a).

\section{Results}

Direct sequencing of the coding sequence failed to detect any variants in both SOD1 and $T A R D B P$ in our case. In contrast, the K17I mutation was identified in the $A N G$ gene. This mutation has already been reported as pathogenic by Wu et al. (2007).

The main neuropathological findings have been described in the previous paper [53]. The anterior and lateral tracts of the spinal cord were severely degenerated (Fig. 1a, b). Additional sampling of the hippocampus showed focal cortical dysplasia in the left parahippocampal gyrus. Boundaries between cell layers were indistinct; the junction between deep cortical layers and white matter was ill defined. Dysmorphic neurons had abnormal orientation, surrounded by a 
loose and fibrillary neuropil. Among them, ballooned cells had an enlarged round soma with eccentric nucleus (Fig. 2j).

The main findings of the immunohistochemistry experiments are summarized in table 2 . A positive labeling was obtained in control adenocarcinoma with two of the tested angiogenin antibodies (polyclonal antibody and MANG-1 monoclonal antibody). Angiogenin was immunodetected in the choroid plexus of patient and control, as well as fibulin-1 (data not shown). Intravascular monocytes were angiogenin reactive in the normal control brain (data not shown). The MANG-1 angiogenin monoclonal antibody showed, in addition, granular intracytoplasmic immunoreactivity in neurons of the controls, in all regions examined, including anterior horns of the spinal cord (Fig. 1d). Intracytoplasmic labeling in the patient and the controls was similar (Fig. 2d) except for a weaker staining of degenerating spinal motor neurons (Fig. 1e). The MANG-1 angiogenin antibody also labeled reactive astrocytes (Fig. 1e, f). This finding was not specific to the $A N G$ mutation case, as labeled astrocytes were occasionally found in control cases in regions with reactive astrogliosis. The atrophic spinal tracts were strongly labeled (Fig. 1c). MANG-1 immunohistochemistry did not detect any abnormal intracytoplamic or intranuclear inclusion in neurons and glial cells. No signal was detected either in smooth muscle fibers or in endothelial cells.

The NIIs that were described in the previous paper, were found in the pyramidal neurons of the hippocampus (Fig. 2), and frontal cortex (medial frontal gyrus) (Fig. 3c), as well as in dystrophic neurons in the left temporal lobe (Fig. 2j). They were not immunolabeled by the antibodies raised against angiogenin but were immunoreactive to smA (smooth muscle alpha actin). No reactivity for smA was found in the NIIs of positive controls with polyglutamic inclusions. The NIIs were not immunoreactive to fibulin-1, $\alpha$-actinin 1 and 2, desmin, FVIII, 
CD34, vimentin and TDP-43 (Fig. 2). They were found to be immunoreactive to p62, as was expected from the previous finding of their ubiquitin positivity.

In addition, immunohistochemistry of p62 and TDP-43 revealed numerous cytoplasmic inclusions in neurons and glial cells in various regions of the CNS including hippocampus, frontal cortex, striatum, medulla and spinal cord (Fig. 3). These cytoplasmic inclusions were not immunoreactive to smA, angiogenin, fibulin-1, $\alpha$-actinin 1 and 2.

Intraneuronal, $\alpha$-synuclein negative Lewy-like inclusions were detected with TDP-43 and phospho-TDP-43 antibodies in the striatum, mesencephalic tegmentum and anterior horns (Fig 3f, Fig 4a-c). TDP-43 positive skein-like inclusions were observed in the anterior horn of the spinal cord and inferior olive (Fig. 3 g-h). A few ring-shape inclusions were detected in the granular cells of the dentate gyrus only with phospho-TDP43 immunohistochemistry (Fig. 4d).

The labeled glial cells had the morphologic features characteristic of oligodendrocytes. The shapes of the inclusions were reminiscent either of the cap-shaped glial cytoplasmic inclusions (GCI) observed in multiple system atrophy (MSA) (Fig $3 \mathrm{c}$ ) or of the coiled bodies described in progressive supranuclear palsy (PSP), corticobasal degeneration (CBD) and argyrophilic grain disease (Fig $3 \mathrm{~b}, \mathrm{~d}$ ), but these inclusions, although ubiquitin positive, were tau and $\alpha$ - synuclein immunonegative. They were better visualized with the p62 and TDP-43 antibodies than with the phospho-TDP-43 antibody.

Major changes in immunoreactivity were also found in the peripheral organs of our case. The peroneal muscle was severely atrophied with a spectacular decrease of $\alpha$-actinin- 2 reactivity specifically in the Z disk (Fig. 5c) compared to both normal (Fig. 5a) and denervated muscle (Fig. $5 b)$. By contrast, detection of sarcomeric $\alpha$-actin was remarkably unchanged in $A N G$ mutation (Fig. 5f), compared to normal (Fig. 5d) and denervated (Fig. 5e) controls. 
In the patient's liver, angiogenin labeling was decreased (Fig. 6a) compared to control samples with severe steatosis (Fig. 6c), fixed for various durations. SmA positive filaments surrounded the liver lobules forming an interconnecting network (Fig. 6b) in the patient and in one of the 6 control cases (which had no neurological disease history and died with acute pancreatitis). SmA positive fibers were only found in the portal and centrolobular areas in control normal liver samples and in 5 out of the six cases with severe steatosis (Fig. 6d).

\section{Discussion}

We have found that motor neuron disease associated with the K17I mutation of the $A N G$ gene is characterized by three types of inclusions : NIIs, cytoplasmic inclusions either neuronal or oligodendroglial.

NIIs : ubiquitin, p62, smA positive NIIs were detected in pyramidal neurons in the hippocampus and frontal cortex. The NIIs were not immunolabeled by $1 \mathrm{C} 2$ antibodies [53] as are those found in polyglutamine disease, or by TDP-43 antibodies as those found in other forms of ALS-dementia or in progranulin mutations. Immunoreactivity of the intranuclear inclusions to p62 is in accordance to their immunoreactivity to ubiquitin and proteasome $19 \mathrm{~S}$, that we had previously reported [53]. P62 immunoreactivity contrasting with TDP-43 negativity in the NIIs observed in our case, is reminiscent of the TDP-43 negative FTLD-U recently identified [29, 39, 49] which, however, were also p62 negative [49].

Angiogenin antibodies raised against full length human did not label either the NIIs nor the cytoplasmic inclusions observed in neurons and glial cells, whatever the duration of fixation. The epitope mapping of the ANG antibodies is not currently available and the possibility remains that a fragment of the protein, not recognized by these antibodies, accumulates in the NIIs. 
Nevertheless, the monoclonal MANG-1 antibody immunostained the cytoplasm of the neurons in all regions examined, in patient and controls, as previously described in the normal spinal cord [64].

In our case, K17I $A N G$ mutation was associated with a sequestration of smA in the nucleus of susceptible neurons in the frontal cortex and the hippocampus. Remarkably, these inclusions were not found in the regions where the most severe neuronal loss was observed such as the spinal cord or the substantia nigra. This suggests that NIIs are transient and occur much earlier than cell death or that they play a protective role - a role that has been documented for the NIIs observed in SCA models [2]. In many hereditary diseases, the accumulated protein is coded by the mutated gene. In the K17I $A N G$ mutation, as in PRGN mutations the NIIs do not contain the abnormal protein [39]. In the PRGN mutations the protein is not translated because the mutant mRNAs decay rapidly $[1,40]$.

Cytoplasmic inclusions: Many p62 and TDP-43 positive intracytoplasmic inclusions were found in neurons and oligodendrocytes throughout the CNS. These inclusions were not labeled by antibodies raised against angiogenin or other related proteins including smA, $\alpha$-actinins and fibulin-1. Their shape and distribution were clearly distinct from those encountered in sporadic ALS.

Lewy-like TDP-43 and phospho-TDP-43 neuronal cytoplasmic inclusions were found in the striatum, mesencephalic tegmentum and anterior horns. Neuronal granular cytoplasmic inclusions with absent nuclear TDP-43 labeling, similar as those observed in the hippocampus in our case, have been previously interpreted as "pre-inclusions" in FTLD-U $[4,9,60]$. The rarity of inclusions in the dendate gyrus, detected only by the phospho-TDP43 antibody, was remarkable in our case. 
The oligodendroglial cytoplasmic inclusions were observed in all the samples of the CNS that we examined. Some TDP-43 oligodendroglial inclusions have previously been described in the medullary tegmentum and inferior olivary nucleus [10], as well as in the cerebral white matter in FTLD-MND [21]. They may be observed in various CNS regions in sporadic ALS cases particularly when associated to TDP-43 neuronal cytoplasmic inclusions in the dentate gyrus [43]. In the present case, they were found in numerous areas of the CNS, representing one of the predominant neuropathologic features. The presence of numerous oligodendroglial inclusions of various types is characteristic of several neurodegenerative diseases such as MSA [46], PSP, CBD, argyrophilic grain disease [3, 33], and more recently in white matter tauopathy with globular glial inclusions [34]. Absence of immunoreactivity of the glial inclusions to $\alpha$-synuclein and tau in the present case ruled out an association with one of these diseases.

Angiogenin, which was first described as an angiogenic factor secreted by tumor cells, has several physiological roles. In culture, angiogenin promotes ribosomal RNA transcription, cellular proliferation, organization of endothelial cells into tube-like structures and supports endothelial cell migration [24, 28, 59]. A strong expression of the protein has been detected in the developing mouse nervous system as well as in post-mitotic motor neurons derived from P19 cells [58]. It is also able to modulate PI-3-kinase/Akt-1 and ERK1/2 that belong to signaling pathways involved in neuron survival [20]. Transfection of wild $A N G$ but not of $A N G$ K40I mutant, protects NSC34 cells against excitotoxic injury. Angiogenin treatment, even after the clinical onset of neurologic signs, increases lifespan and motor function in SOD1 mutant mice [31].

The dominant mode of inheritance of ALS related to angiogenin mutation favors a toxic gain of function. However, most $A N G$ mutations identified in ALS patients are associated with 
functional loss of angiogenic activity [7, 64]. Six of the seven ALS-linked mutations including K17I markedly decrease the ribonuclease activity of angiogenin [7]. In contrast with the mutations S28N, P112L [64] R31A and R31K [18] impairment of the nuclear translocation has not been observed with the K17I mutation [64].

Accumulation of actin due to the $\mathrm{K} 17 \mathrm{I} A N G$ mutation is probably related to a disturbance of angiogenin-actin interaction. Actin is a ubiquitous molecule of the cytosol that plays a key role in cell structure, cell motility and contraction in both muscle and non muscle cells. Mammals produce six isoforms in a tissue specific fashion encoded by separated genes [62] and divided into three classes $(\alpha, \beta, \gamma)$ according to their isoelectric point. Alpha-actins are found in striate and smooth muscles whereas $\beta$ and $\gamma$ isoforms are prominent in non-muscle cells. Both exogenous and endogenous angiogenin is able to interact with various actin isoforms. Smooth muscle $\alpha$-actin has been identified as the $42-\mathrm{kDa}$ angiogenin receptor protein at the surface of endothelial cells $[23,26,41]$. Actin binding to exogenous angiogenin at the surface of the cell induces membrane actin polymerization [26]. This surface interaction also induces endocytosis of angiogenin before translocation to the nucleus [42]. Actin polymerization and angiogenin endocytosis are critical steps in the process of angiogenin-dependent neovascularization [26, 42]. In addition, angiogenin binding to $\alpha$-actin promotes Akt-1 activation [31, 32]. Akt-1 belongs to the serine/threoninespecific protein kinase family and is involved in cellular survival pathways, by inhibiting apoptotic processes. It has been recently shown to play a key role in motor neuron protection in vitro and in vivo [31].

Endogenous angiogenin is able to interact with intracellular actin, a major component of the cytoskeleton by the mediation of cytosolic $\alpha$-actinin-2 [27], which is a member of the spectrin/dystrophin superfamily [56]. Alpha-actinins form anti-parallel rod-shaped dimers that 
bundle actin filaments in cytoskeleton frameworks [56]. In mammalian cells four $\alpha$-actinin genes produce at least six different isoforms, with specific tissue type and expression profiles. In skeletal and cardiac muscle $\alpha$-actinin- 2 is localized in the $\mathrm{Z}$ disk and cross-links anti-parallel actin filaments coming from adjacent sarcomeres [56]. In the central nervous system, $\alpha$-actinin-2 is a postsynaptic protein which colocalizes in dendritic spines with the NR1 and NR2B subunits of Nmethyl-D-aspartate (NMDA) glutamate receptors $[11,65]$. $\alpha$-actinin-2 binds the receptors to the actin cytoskeleton the integrity of which is mandatory for their function [51]. In addition to neuronal degeneration, it is noteworthy that this patient presented with apparently asymptomatic cortical dysplasia in the left temporal lobe. Some dystrophic neurons contained intranuclear inclusions arguing for an effect of the mutation on neuronal migration.

Specific loss of $\alpha$-actinin-2 in the striate muscle associated with $\mathrm{Z}$ disk disorganization is suggestive of a direct muscular toxicity of the mutation that could add its effect to the loss of motor neurons. The muscle deficiency may have played a role in the rapid course of the disease that led the patient to mechanical ventilation only a few months after onset.

Fatty liver disease observed in our patient was unusually severe compared to other ALS patients [12]. We do not exclude that steatosis was an incidental feature due to metabolic exogenous factors. Nevertheless, $A N G$ mutation could influence angiogenesis and lipid metabolism in the liver. Angiogenesis plays a role in the modulation of adipogenesis [5] and angiogenin is one of the downregulated genes in the C57BL/6J mice strain characterized by a high level of hepatic triglycerides [38]. Liver is normally the site of the highest angiogenin gene expression in adult [63] although the intensity of labeling has been reported to be quite low in non tumoral liver [22]. It was particularly low in our patient compared to controls with steatosis. More striking was the pattern of expression of smA which was compatible with an increased 
polymerization of $\alpha$-actin. Hepatic sinusoids are normally deprived of vascular wall. They are limited by a layer of endothelial cells surrounded by stellate and Kupfer's cells, separated from hepatocytes by space of Disse. In our case there was formation of an additional actin layer located under the endothelial cells and organized in a branching network. It has been shown that some catalytically inactive angiogenin mutants were still able to induce actin polymerization [55]. Its hypothetic role in liver regeneration or steatosis remains to be explored. The liver could be another site of angiogenin dysfunction besides the CNS and muscle in K17I ANG mutations.

TARDBP or TDP-43 is a DNA and RNA-binding protein which regulates transcription and splicing. An abnormal form of the protein, hyperphosphorylated and truncated, has been found to be accumulated in the cytoplasm, and sometimes nucleus, of neurons and glial cells in many cases of sporadic ALS and in FTLD-U. TDP-43 immunoreactivity is absent from the nucleus of cells containing cytoplasmic inclusions suggesting that pathogenesis of these proteinopathies could be due to the loss of normal TDP-43 function in the nucleus [36]. In PGRN gene mutations, causing familial FTLD-U with TDP-43 intranuclear and intracytoplasmic aggregates, genetic variability of microRNAs (miRNA) that bind mRNAs, can significantly modulate the translation of the protein, increasing the risk to develop the disease [47]. Two other genes coding for proteins involved in RNA processing have been found to be mutated in familial ALS. One is $S E T X$ coding for senataxin, which belongs to the helicase family that are involved in DNA repair and production of RNA. The other is the FUS/TLS (fusing in sarcoma/translated in liposarcoma) gene coding for another DNA/RNA binding protein [35, 61]. Analysis of the brain and spinal cords of ALS patients carrying the FUS/TLS mutations showed intracytoplasmic neuronal aggregates reminiscent of TDP-43 aggregates [35, 61]. Detection of TDP-43 in the cytoplasm of neurons and glial cells in this case of $A N G$ K17I mutation and recent discovery of 
angiogenin role in tRNA cleavage and inhibition of protein translation [66] support the hypothesis that angiogenin-related ALS pathogenesis involves also a defect in RNA maturation.

However, in contrast to TARDBP and FUS/TLS mutations, it is not the mutated protein that accumulates in the K17I $A N G$ mutation, but smA, probably a partner of angiogenin. Additional accumulation of TDP-43 in neurons and oligodendrocytes in cells different from those with smA positive NIIs suggest associated pathways of toxicity.

The present case, which is, to the best of our knowledge, the first neuropathology report of an $A N G$ mutation, illustrates in several ways the toxicity related to this mutation, including alteration of neuronal and muscle fibers survival, and possible associated impairment of neuronal cell migration and lipid metabolism. Neuropathologically, the salient characteristics of the case were smA and ubiquitin positive NIIs, and TDP-43 positive oligodendroglial and neuronal cytoplasmic inclusions. The anti-smooth muscle $\alpha$-actin antibody can be a useful tool for the neuropathological analysis of ALS. ANG mutations should be looked for in patients presenting with rapidly progressing ALS, as well as in patients with cortical dysplasia or unexplained severe steatosis.

It is important to recognize that RNA maturation related to angiogenin, TDP-43 and FUS/TLS plays a key role in the pathogenesis of ALS.

\section{Acknowledgements}

Many thanks to the technical staff of Escourolle laboratory; to Drs Odile Dubourg, Eva Comperat, and Frédéric Charlotte who provided some of the control cases; to the Institute of 
Myology and Laboratory of Pathology, who provided some of the antibodies and to Pr. Umberto De Girolami for helpful advice on the manuscript. 


\section{Legends of the figures}

\section{Figure 1. Spinal cord pathology}

a-c Low magnification of spinal cord sections stained with 2F11 anti-neurofilament antibody (a) and with Bodian silver impregnation coupled with Luxol fast blue (b), both showing severe degeneration of the anterior and lateral tracts. By contrast, MANG-1 angiogenin imunohistochemistry (c) strongly labels the degenerated tracts. Bars $=0,5 \mathrm{~cm}$. d-f. Angiogenin immunohistochemistry in the anterior horn of the spinal cord in a control (d) and in the patient $(\mathrm{e}, \mathrm{f})$. The anti-angiogenin MANG-1 monoclonal antibody stains the cytoplasm of normal motor neurons (d). In the patient, severe neuronal loss is associated with a decrease in angiogenin cytoplasmic labeling (e : arrow head). Reactive astrocytes are strongly labeled with the MANG-1 antibody (e, f : arrows). Bars $=10 \mu \mathrm{m}(\mathrm{d}), 20 \mu \mathrm{m}(\mathrm{e}, \mathrm{f})$.

\section{Figure 2. Immunoreactivity pattern of hippocampal NIIs.}

NII immunoreactivity for p62 (a) and smooth muscle actin (b). Absence of immunoreactivity for : $\alpha$-actinin-2 (c : arrow), angiogenin (d), fibulin-1 (e : arrow), $\alpha$-actinin-1 (f : arrow), $\beta$-actin (g), TDP-43 (h : arrow), sarcomeric $\alpha$-actin (k : arrow) and desmin (1 : arrow). Note normal cytoplasmic labeling of pyramidal neurons in the hippocampus with the MANG-1 monoclonal antibody, even in neurons containing a NII (d). Likewise, NIIs could be observed together with a normal TDP-43 nuclear labeling (h : arrow head). Diffuse granular cytoplasmic immunoreactivity (arrow), and loss of normal nuclear TDP-43 positivity (arrow head), without NII, in a pyramidal cell of the hippocampus (i). Bars $=10 \mu \mathrm{m}$. 
Cortical dysplasia in the left hippocampus (j): ubiquitin positive NII in a ballooned neuron. Bar = $40 \mu \mathrm{m}$.

\section{Figure 3. Oligodendroglial and neuronal cytoplasmic inclusions.}

a-f : Oligodendroglial inclusions. P62 immunoreactive oligodendrial inclusions in the medulla oblongata (a), the hippocampus (b), and midfrontal gyrus (c : arrow). Note in c, a NII (arrow head) similar to those described in the hippocampus (Fig 2a). TDP-43 immunoreactive oligodendroglial inclusions in the hippocampus ( $\mathrm{d}$ : arrow) and in the striatum (e, $\mathrm{f}:$ arrow). Note the absence of nuclear labeling in cells bearing cytoplasmic inclusions compared to normal nuclear labeling in neighboring oligodendrocytes (d, arrow head).

f-h Neuronal intracytoplasmic inclusions. In the striatum, "Lewy like” TDP-43 positive intraneuronal inclusions (f, arrow head). "Skein-like" TDP-43-positive intraneuronal inclusions in the spinal cord (g) and the inferior olive (h). Bars $=8 \mu \mathrm{m}(\mathrm{b}), 10 \mu \mathrm{m}$ (a, c-e, g, h), and $40 \mu \mathrm{m}$ (f) respectively.

\section{Figure 4. pTDP43 immunoreactivity}

Neuronal intracytoplasmic pTDP-43-positive inclusions in mesencephalon (a), striatum (b), anterior horns (c), dentate gyrus (d). Bars $=10 \mu \mathrm{m}$.

\section{Figure 5. Patterns of immunoreactivity in the muscle}

a-c : $\alpha$-actinin-2; d-f : sarcomeric $\alpha$-actin. Patterns of staining in normal muscle (a, d), in denervated muscle $(\mathrm{b}, \mathrm{e})$ and in ANG mutation (c, f). In ANG mutation, sparing of sarcomeric $\alpha$ actin is noticeable, compared to the severe in decrease of $\alpha$-actinin-2. Bars $=100 \mu \mathrm{m}$. 
Figure 6. Patterns of immunoreactivity in the liver

a-c : decreased angiogenin immunostaining in the liver of the patient with K17I $A N G$ mutation (a) compared to a control with severe steatosis (c).

b-d : increased smA staining in the liver of the patient with K17I $A N G$ mutation (b) compared to a control with severe steatosis (d). Bars $=100 \mu \mathrm{m}$ 


\begin{tabular}{|c|c|c|c|c|c|c|c|}
\hline Antigen & $\begin{array}{c}\text { Poly/mono } \\
\text { clonal }\end{array}$ & Producer & Immunogen & Clone & $\begin{array}{c}\text { Pretreatmen } \\
\mathbf{t}\end{array}$ & Dilution & $\begin{array}{c}\text { Incubation } \\
\text { time }\end{array}$ \\
\hline $\begin{array}{l}\alpha-\text { actin } \\
\text { (smooth } \\
\text { muscle) }\end{array}$ & $\begin{array}{l}\text { Monoclonal } \\
\text { (mouse) }\end{array}$ & Dako® & $\begin{array}{l}\text { N-terminal of the } \alpha \\
\text { smooth cell actin }\end{array}$ & $1 \mathrm{~A} 4$ & $\begin{array}{c}\mathrm{CC} 1 \AA 8 \mathrm{~min} \\
\text { at } 95^{\circ} \mathrm{C}\end{array}$ & $1: 500$ & $\begin{array}{l}20 \mathrm{~min} \\
+4^{\circ} \mathrm{C}\end{array}$ \\
\hline $\begin{array}{c}\alpha-\text { actin } \\
\text { (sarcomeric) }\end{array}$ & $\begin{array}{l}\text { Monoclonal } \\
\text { (mouse) }\end{array}$ & Dako® & $\begin{array}{l}\alpha \text {-skeletal and } \alpha- \\
\text { cardiac muscle } \\
\text { actins }\end{array}$ & $\begin{array}{l}\text { Alpha- } \\
\text { Sr-1 }\end{array}$ & $\mathrm{CC} 1 \circledR$ & $1: 50$ & $\begin{array}{l}32 \min \\
+37^{\circ} \mathrm{C}\end{array}$ \\
\hline$\beta$-actin & $\begin{array}{c}\text { Monoclonal } \\
\text { (mouse) }\end{array}$ & Abcam $®$ & $\begin{array}{l}\text { N-terminal of the } \beta \\
\text { isoform of actin }\end{array}$ & AC-15 & CC1@ 30min & $1: 5000$ & $\begin{array}{l}32 \mathrm{~min} \\
+37^{\circ} \mathrm{C}\end{array}$ \\
\hline $\begin{array}{c}\alpha-\operatorname{actinin} \\
(\mathrm{H}-2)\end{array}$ & $\begin{array}{l}\text { Monoclonal } \\
\text { (mouse) }\end{array}$ & $\begin{array}{c}\text { Santa Cruz } \\
\text { Biotechnology, } \\
\text { Inc. } \AA\end{array}$ & $\begin{array}{l}\text { C-terminal amino } \\
\text { acids } 593-892 \text { of } \\
\text { human } \alpha \text {-actinin- } 1\end{array}$ & $\mathrm{H}-2$ & $\begin{array}{c}\mathrm{CC} 1 \AA 30 \mathrm{~min} \\
\text { at } 95^{\circ} \mathrm{C}\end{array}$ & $1: 500$ & $\begin{array}{l}28 \min \\
+37^{\circ} \mathrm{C}\end{array}$ \\
\hline $\begin{array}{c}\alpha-\operatorname{actinin} 2 \\
(\mathrm{ACTN} 2)\end{array}$ & $\begin{array}{l}\text { Polyclonal } \\
\text { (rabbit) }\end{array}$ & $\begin{array}{c}\text { Lifespan } \\
\text { biosciences } ®\end{array}$ & $\begin{array}{c}\text { Human } \alpha \text {-actinin-2, } \\
\text { skeletal muscle } \\
\text { isoform }\end{array}$ & - & $\begin{array}{c}\mathrm{CC} 1 \AA 30 \mathrm{~min} \\
\text { at } 95^{\circ} \mathrm{C}\end{array}$ & $1: 100$ & $\begin{array}{l}32 \min \\
+37^{\circ} \mathrm{C}\end{array}$ \\
\hline Angiogenin & $\begin{array}{l}\text { Polyclonal } \\
\text { (goat) } \\
\text { IgG }\end{array}$ & R\&D systems® & $\begin{array}{l}\text { Full length } \\
\text { recombinant } \\
\text { human angiogenin }\end{array}$ & - & $\begin{array}{c}\text { DakoCytomat } \\
\text { ion }{ }^{\circledR} \text { Buffer } \\
\text { pH }=9 \\
\text { microwave }\end{array}$ & $1: 20$ & $\begin{array}{l}\text { Overnight } \\
\quad+4^{\circ} \mathrm{C}\end{array}$ \\
\hline Angiogenin & $\begin{array}{c}\text { Monoclonal } \\
\text { (mouse) } \\
\text { IgG }\end{array}$ & Sigma ${ }^{\circledR}$ & $\begin{array}{c}\text { Full length } \\
\text { recombinant } \\
\text { human angiogenin }\end{array}$ & $\begin{array}{c}14017 . \\
7\end{array}$ & $\begin{array}{c}\text { DakoCytomat } \\
\text { ion® Buffer } \\
\text { pH=9 } \\
\text { microwave }\end{array}$ & $1: 500$ & $\begin{array}{l}\text { Overnight } \\
\quad+4^{\circ} \mathrm{C}\end{array}$ \\
\hline Angiogenin & $\begin{array}{c}\text { Monoclonal } \\
\text { (mouse) } \\
\text { IgM }\end{array}$ & $\begin{array}{c}\mathrm{AbD} \\
\text { serotec }{ }^{\circledR}\end{array}$ & $\begin{array}{c}\text { Full length } \\
\text { recombinant } \\
\text { human angiogenin }\end{array}$ & $\begin{array}{c}\text { MAN } \\
\text { G-1 }\end{array}$ & $\begin{array}{c}\text { Ventana }{ }^{\circledR} \\
\text { Protease } 1 \\
\text { Buffer } \\
\text { pH=7.2 } \\
\text { microwave }\end{array}$ & $1: 200$ & $\begin{array}{l}60 \mathrm{~min} \\
+37^{\circ} \mathrm{C}\end{array}$ \\
\hline CD34 & $\begin{array}{c}\text { Monoclonal } \\
\text { (mouse) }\end{array}$ & Dako® & $\begin{array}{c}\text { Human endothelial } \\
\text { venules }\end{array}$ & $\begin{array}{l}\text { QBEe } \\
\text { nd10 }\end{array}$ & $\begin{array}{c}\mathrm{CC} 1 \AA 30 \mathrm{~min} \\
\text { at } 95^{\circ} \mathrm{C} \\
\end{array}$ & $1: 50$ & $\begin{array}{l}20 \mathrm{~min} \\
+37^{\circ} \mathrm{C} \\
\end{array}$ \\
\hline Desmin & $\begin{array}{l}\text { Monoclonal } \\
\text { (mouse) }\end{array}$ & Dako® & $\begin{array}{l}\text { Desmin purified } \\
\text { from human } \\
\text { muscle }\end{array}$ & D33 & $\begin{array}{c}\mathrm{CC} 1 \AA 30 \mathrm{~min} \\
\text { at } 95^{\circ} \mathrm{C}\end{array}$ & $1: 50$ & $\begin{array}{l}20 \mathrm{~min} \\
+37^{\circ} \mathrm{C}\end{array}$ \\
\hline Factor VIII & $\begin{array}{l}\text { Polyclonal } \\
\text { (rabbit) }\end{array}$ & Dako® & Human plasma & - & $\mathrm{CC} 1 \AA$ & $1: 400$ & $\begin{array}{l}20 \mathrm{~min} \\
+37^{\circ} \mathrm{C}\end{array}$ \\
\hline Fibulin-1 & $\begin{array}{l}\text { Polyclonal } \\
\text { (rabbit) }\end{array}$ & $\begin{array}{c}\text { Atlas } \\
\text { antibodies } ®\end{array}$ & $\begin{array}{l}\text { Recombinant } \\
\text { protein epitope } \\
\text { signature tag } \\
\text { (PrEST) }\end{array}$ & - & $\begin{array}{c}\mathrm{CC} 1 \AA 30 \mathrm{~min} \\
\text { at } 95^{\circ} \mathrm{C}\end{array}$ & $1: 50$ & $\begin{array}{l}32 \min \\
+37^{\circ} \mathrm{C}\end{array}$ \\
\hline Neurofilament & $\begin{array}{l}\text { Monoclonal } \\
\text { (mouse) }\end{array}$ & Dako@ & $\begin{array}{c}70 \mathrm{kDa} \text { subunit of } \\
\text { neurofilament } \\
\text { (axons) }\end{array}$ & $2 \mathrm{~F} 11$ & $\mathrm{CC} 1 \AA$ & $1: 2000$ & $\begin{array}{l}32 \min \\
+37^{\circ} \mathrm{C}\end{array}$ \\
\hline p62 lck ligand & $\begin{array}{l}\text { Monoclonal } \\
\text { (mouse) }\end{array}$ & $\begin{array}{c}\text { BD } \\
\text { Biosciences } ®\end{array}$ & $\begin{array}{c}\text { Human p62 lck } \\
\text { ligand aa. } 257-437\end{array}$ & $\begin{array}{l}257- \\
437\end{array}$ & $\begin{array}{c}\text { Citrate Buffer } \\
\text { pH=6 } \\
\text { microwave }\end{array}$ & $1: 1000$ & $\begin{array}{l}\text { Overnight } \\
\quad+4^{\circ} \mathrm{C}\end{array}$ \\
\hline$\alpha-$ Synuclein & $\begin{array}{l}\text { Monoclonal } \\
\text { (mouse) }\end{array}$ & Novocastra ${ }^{\circledR}$ & $\begin{array}{c}\text { Full length } \\
\text { recombinant alpha- } \\
\text { synuclein }\end{array}$ & KM51 & $\begin{array}{c}\mathrm{CC} 1 \AA 30 \mathrm{~min} \\
\text { at } 95^{\circ} \mathrm{C}\end{array}$ & $1: 20$ & $\begin{array}{l}56 \min \\
+37^{\circ} \mathrm{C}\end{array}$ \\
\hline
\end{tabular}




\begin{tabular}{|c|c|c|c|c|c|c|c|}
\hline $\begin{array}{c}\text { Phospho-TDP- } \\
43 \\
\text { pS409/410-2 }\end{array}$ & $\begin{array}{l}\text { Polyclonal } \\
\text { (rabbit) }\end{array}$ & $\begin{array}{c}\text { Cosmo Bio Co. } \\
\text { Ltd® }\end{array}$ & $\begin{array}{c}\text { Phosphorylated } \\
\text { full length TDP-43 } \\
\text { CMDSKS }(\mathrm{p}) \mathrm{S}(\mathrm{p}) \mathrm{G} \\
\text { WGM,S }(\mathrm{p}): \\
\text { phosphoserine } \\
409 / 410\end{array}$ & - & $\mathrm{CC} 1 \AA$ & $1: 5000$ & $\begin{array}{l}60 \mathrm{~min} \\
+37^{\circ} \mathrm{C}\end{array}$ \\
\hline $\begin{array}{l}\text { TARDBP } \\
\text { (TDP-43) }\end{array}$ & $\begin{array}{l}\text { Polyclonal } \\
\text { (rabbit) }\end{array}$ & $\begin{array}{l}\text { Protein Tech } \\
\text { Group } \AA\end{array}$ & $\begin{array}{c}\text { Human } \\
\text { recombinant } \\
\text { protein }\end{array}$ & - & $\begin{array}{c}\mathrm{CC} 1 \AA 60 \mathrm{~min} \\
\text { at } 95^{\circ} \mathrm{C}\end{array}$ & $1: 1000$ & $\begin{array}{l}80 \mathrm{~min} \\
+20^{\circ} \mathrm{C}\end{array}$ \\
\hline Tau & $\begin{array}{l}\text { Polyclonal } \\
\text { (rabbit) }\end{array}$ & Dako® & $\begin{array}{c}\text { C terminal of } \\
\text { human tau protein } \\
\text { expressed in E.coli }\end{array}$ & - & $\begin{array}{l}\mathrm{CC} 1 \AA 8 \mathrm{~min} \\
\text { at } 95^{\circ} \mathrm{C} \\
+\mathrm{FA} 5 \mathrm{~min} \\
\end{array}$ & $1: 500$ & $\begin{array}{l}32 \min \\
+37^{\circ} \mathrm{C}\end{array}$ \\
\hline Ubiquitin & $\begin{array}{l}\text { Polyclonal } \\
\text { (rabbit) }\end{array}$ & Dako® & $\begin{array}{l}\text { Ubiquitin isolated } \\
\text { from cow } \\
\text { erythrocytes }\end{array}$ & - & $\begin{array}{c}\mathrm{CC} 1{ }^{\circledR} \text { at } \\
95^{\circ} \mathrm{C} \\
30 \mathrm{~min} \\
+ \text { FA } 10 \mathrm{~min} \\
\end{array}$ & $1: 500$ & $\begin{array}{l}32 \min \\
+4^{\circ} \mathrm{C}\end{array}$ \\
\hline Vimentin & $\begin{array}{l}\text { Monoclonal } \\
\text { (mouse) }\end{array}$ & Dako® & $\begin{array}{l}\text { Purified vimentin } \\
\text { from porcine eye } \\
\text { lens }\end{array}$ & V9 & $\mathrm{CC} 1 \circledR$ & $1: 50$ & $\begin{array}{l}32 \min \\
+4^{\circ} \mathrm{C}\end{array}$ \\
\hline
\end{tabular}

Table 1: Immunohistochemical methods.

$\boldsymbol{C C 1}$, a proprietary high pH (=8) buffer; $\boldsymbol{F} \boldsymbol{A}$ : formic acid. 


\begin{tabular}{|c|c|c|c|c|c|}
\hline & \multicolumn{3}{|c|}{ CNS } & \multirow{2}{*}{$\begin{array}{l}\text { Striated } \\
\text { muscle }\end{array}$} & \multirow[t]{2}{*}{ Liver } \\
\hline & $\begin{array}{l}\text { Hippocampal and } \\
\text { frontal NII }\end{array}$ & $\begin{array}{c}\text { Neuronal } \\
\text { intracytoplasmic } \\
\text { inclusions }\end{array}$ & $\begin{array}{c}\text { Oligodendroglial } \\
\text { intracytoplasmic } \\
\text { inclusions }\end{array}$ & & \\
\hline Angiogenin & 0 & 0 & 0 & 0 & - \\
\hline $\begin{array}{l}\text { Smooth } \\
\text { muscle } \alpha- \\
\text { actin }\end{array}$ & + & 0 & 0 & 0 & ++ \\
\hline $\begin{array}{c}\text { Sarcomeric } \\
\alpha \text {-actin }\end{array}$ & 0 & 0 & 0 & + & 0 \\
\hline$\beta$-actin & 0 & 0 & 0 & 0 & 0 \\
\hline$\alpha$-actinin- 1 & 0 & 0 & 0 & 0 & 0 \\
\hline$\alpha$-actinin- 2 & 0 & 0 & 0 & - & 0 \\
\hline Fibulin-1 & 0 & 0 & 0 & 0 & 0 \\
\hline $\mathrm{p}-62$ & + & + & + & 0 & 0 \\
\hline $\begin{array}{l}\text { Phospho- } \\
\text { TDP-43 }\end{array}$ & 0 & + & + & 0 & 0 \\
\hline TDP-43 & 0 & + & + & 0 & 0 \\
\hline Ubiquitin & + & + & + & 0 & 0 \\
\hline
\end{tabular}

Table 2 : Main immunohistochemistry findings in K17I ANG mutation.

$0=$ no significant change compared to normal; $+/++=$ positive signal of low $(+)$ or high $(++)$ intensity; $-=$ abnormally low detection. 


\section{References}

1. Baker M, Mackenzie I, Pickering-Brown S et al (2006) Mutations in progranulin cause tau-negative frontotemporal dementia linked to chromosome 17. Nature 442:916-919

2. Bowman A, Yoo S, Dantuma N, Zoghbi H (2005) Neuronal dysfunction in a polyglutamine disease model occurs in the absence of ubiquitin-proteasome system impairment and inversely correlates with the degree of nuclear inclusion formation. Hum Mol Genet 14:679-691

3. Braak H, Braak E (1989) Cortical and subcortical argyrophilic grains characterize a disease associated with adult onset dementia. Neuropathol Appl Neurobiol 15:13-26

4. Cairns N, Neumann M, Bigio E et al (2007) TDP-43 in familial and sporadic frontotemporal lobar degeneration with ubiquitin inclusions. Am J Pathol 171:227-240

5. Cao Y (2007) Angiogenesis modulates adipogenesis and obesity. J Clin Invest 117:23622368

6. Chen Y, Bennett C, Huynh H et al (2004) DNA/RNA helicase gene mutations in a form of juvenile amyotrophic lateral sclerosis (ALS4). Am J Hum Genet 74:1128-1135

7. Crabtree B, Thiyagarajan N, Prior S et al (2007) Characterization of human angiogenin variants implicated in amyotrophic lateral sclerosis. Biochemistry 46:11810-11818

8. Daoud H, Valdmanis P, Kabashi E et al (2008) Contribution of TARDBP mutations to sporadic amyotrophic lateral sclerosis. J Med Genet: Epub ahead of print

9. Davidson Y, Kelley T, Mackenzie I et al (2007) Ubiquitinated pathological lesions in frontotemporal lobar degeneration contain the TAR DNA-binding protein, TDP-43. Acta Neuropathol 113:521-533

10. Dickson D, Josephs K, Amador-Ortiz C (2007) TDP-43 in differential diagnosis of motor neuron disorders. Acta Neuropathol 114:71-79

11. Dunah A, Wyszynski M, Martin D, Sheng M, Standaert D (2000) $\alpha$-actinin-2 in rat striatum: localization and interaction with NMDA glutamate receptor subunits. Brain Res Mol Brain Res 79:77-87

12. Dupuis L, Corcia P, Fergani A et al (2008) Dyslipidemia is a protective factor in amyotrophic lateral sclerosis. Neurology 70:988-989

13. Etoh T, Shibuta K, Barnard G, Keitano S, Mori M (2000) Angiogenin expression in human colorectal cancer : the role of focal macrophage infiltration. Clin Cancer Res 6:3545-3551

14. Fernández-Santiago R, Hoenig S, Lichtner $\mathrm{P}$ et al (2009) Identification of novel Angiogenin (ANG) gene missense variants in German patients with amyotrophic lateral sclerosis. J Neurol 2009: Epub ahead of print

15. Fett J, Strydom D, Lobb R et al (1985) Isolation and characterization of angiogenin, an angiogenic protein from human carcinoma cells. Biochemistry 24:5480-5486

16. Gitcho M, Baloh R, Chakraverty S et al (2008) TDP-43 A315T mutation in familial motor neuron disease. Ann Neurol 63:535-538 
17. Greenway M, Alexander M, Ennis S et al (2004) A novel candidate region for ALS on chromosome 14q11.2. Neurology 63:1936-1938

18. Greenway M, Andersen P, Russ C et al (2006) ANG mutations segregate with familial and "sporadic" amyotrophic lateral sclerosis. Nat Genet 30:411-413

19. Hatzi E, Badet J (1999) Expression of receptors for human angiogenin in vascular smooth muscle cells. Eur J Biochem 260:825-832

20. Hetman M, Gozdz A (2004) Role of extracellular signal regulated kinases 1 and 2 in neuronal survival. Eur J Biochem 271:2050-2055

21. Hiji M, Takahashi T, Fukuba H, Yamashita H, Kohriyama T, Matsumoto M (2008) White matter lesions in the brain with frontotemporal lobar degeneration with motor neuron disease: TDP-43-immunopositive inclusions co-localize with p62, but not ubiquitin. Acta Neuropathol 116:183-191

22. Hisai H, Kato J, Kobune $M$ et al (2003) Increased expression of angiogenin in hepatocellular carcinoma in correlation with tumor vascularity. Clin Cancer Res 9:48524859

23. Hu G, Chang S, Riordan J, Vallee B (1991) An angiogenin-binding protein from endothelial cells. Proc Natl Acad Sci USA 88:2227-2231

24. Hu G, Riordan J, Vallee B (1994) Angiogenin promotes invasiveness of cultured endothelial cells by stimulation of cell-associated proteolytic activities. Proc Natl Acad Sci USA 91:12096-12100

25. Hu G, Riordan J, Vallee B (1997) A putative angiogenin receptor in angiogeninresponsive human endothelial cells. Proc Natl Acad Sci U S A 94:2204-2209

26. Hu G, Strydom D, Fett J, Riordan J, Vallee B (1993) Actin is a binding protein for angiogenin. Proc Natl Acad Sci USA 90:1217-1221

27. Hu H, Gao X, Sun Y, Zhou J, Yang M, Xu Z (2005) $\alpha$-actinin-2, a cytoskeletal protein, binds to angiogenin. Biochem Biophys Res Commun 329:661-667

28. Jimi S, Ito K, Kohno K, Kuwano M, Itagaki Y, Ishikawa H (1995) Modulation by bovine angiogenin of tubular morphogenesis and expression of plasminogen activator in bovine endothelial cells. Biochem Biophys Res Commun 211:476-483

29. Josephs K, Lin W, Ahmed Z, Stroh D, Graff-Radford N, Dickson D (2008) Frontotemporal lobar degeneration with ubiquitin-positive, but TDP-43-negative inclusions. Acta Neuropathol 116:159-167

30. Kabashi E, Valdmanis P, Dion P et al (2008) TARDBP mutations in individuals with sporadic and familial amyotrophic lateral sclerosis. Nat Genet 40:572-574

31. Kieran D, Sebastia J, Greenway M et al (2008) Control of motoneuron survival by angiogenin. J Neurosci 28:14056-14061

32. Kim H, Kang D, Kim H, Kang S, Chang S (2007) Angiogenin-induced protein kinase $\mathrm{B} / \mathrm{Akt}$ activation is necessary for angiogenesis but is independent of nuclear translocation of angiogenin in HUVE cells. Biochem Biophys Res Commun 352:509-513

33. Komori T (1999) Tau-positive glial inclusions in progressive supranuclear palsy, corticobasal degeneration and Pick's disease. Brain Pathol 9:663-679

34. Kovacs G, Majtenyi K, Spina S et al (2008) White matter tauopathy with globular glial inclusions: a distinct sporadic frontotemporal lobar degeneration. J Neuropathol Exp Neurol 67:963-975 
35. Kwiatkowski T, Bosco D, Leclerc A et al (2009) Mutations in the FUS/TLS gene on chromosome 16 cause familial amyotrophic lateral sclerosis. Science 323:1205-1208

36. Lagier-Tourenne C, Cleveland D (2009) Rethinking ALS: the FUS about TDP-43. Cell 136:1001-1004

37. Landers J, Leclerc A, Shi L et al (2008) New VAPB deletion variant and exclusion of VAPB mutations in familial ALS. Neurology 70:1179-1185

38. Lin X, Yue P, Chen Z, Schonfeld G (2005) Hepatic triglyceride contents are genetically determined in mice: results of a strain survey. Am J Physiol Gastrointest Liver Physiol 288:G1179-G1189

39. Mackenzie I, Baker M, Pickering-Brown S et al (2006) The neuropathology of frontotemporal lobar degeneration caused by mutations in the progranulin gene. Brain 129:3081-3090

40. Maquat L (2004) Nonsense-mediated mRNA decay: splicing, translation and mRNP dynamics. Nat Rev Mol Cell Biol 5:89-99

41. Moroianu J, Fett J, Riordan J, Vallee B (1993) Actin is a surface component of calf pulmonary artery endothelial cells in culture. Proc Natl Acad Sci USA 90:3815-3819

42. Moroianu J, Riordan J (1994) Nuclear translocation of angiogenin in proliferating endothelial cells is essential to its angiogenic activity. Proc Natl Acad Sci USA 91:16771681

43. Nishihira Y, Tan C, Onodera O et al (2008) Sporadic amyotrophic lateral sclerosis: two pathological patterns shown by analysis of distribution of TDP-43-immunoreactive neuronal and glial cytoplasmic inclusions. Acta Neuropathol 116:169-182

44. Nishimura A, Mitne-Neto M, Silva $\mathrm{H}$ et al (2004) A mutation in the vesicle-trafficking protein VAPB causes late-onset spinal muscular atrophy and amyotrophic lateral sclerosis. Am J Hum Genet 75:822-831

45. Oosthuyse B, Moons L, Storkebaum E et al (2001) Deletion of the hypoxia-response element in the vascular endothelial growth factor promoter causes motor neuron degeneration. Nat Genet 28:131-138

46. Papp M, Kahn J, Lantos P (1989) Glial cytoplasmic inclusions in the CNS of patients with multiple system atrophy (striatonigral degeneration, olivopontocerebellar atrophy and Shy-Drager syndrome). J Neurol Sci 94:79-100

47. Rademakers R, Eriksen J, Baker $M$ et al (2008) Common variation in the miR-659 binding-site of GRN is a major risk factor for TDP43-positive frontotemporal dementia. Hum Mol Genet 17:3631-3642

48. Roark E, Keene D, Haudenschild C, Godyna S, Little C, Argraves W (1995) The association of human fibulin-1 with elastic fibers: an immunohistological, ultrastructural, and RNA study. J Histochem Cytochem 43:401-411

49. Roeber S, Mackenzie I, Kretzschmar H, Neumann M (2008) TDP-43-negative FTLD-U is a significant new clinico-pathological subtype of FTLD Acta Neuropathol 116:147-157

50. Rosen D, Siddique T, Patterson D et al (1993) Mutations in $\mathrm{Cu} / \mathrm{Zn}$ superoxide dismutase gene are associated with familial amyotrophic lateral sclerosis. Nature 362:59-62

51. Rosenmund C, Westbrook G (1993) Calcium-induced actin depolymerization reduces NMDA channel activity. Neuron 10:805-814

52. Rutherford N, Zhang Y, Baker M et al (2008) Novel mutations in TARDBP (TDP-43) in patients with familial amyotrophic lateral sclerosis. PLoS Genet 4:e1000193 
53. Seilhean D, Takahashi J, El Achimi K et al (2004) Amyotrophic lateral sclerosis with neuronal intranuclear protein inclusions. Acta Neuropathol 108:81-87

54. Shapiro R, Strydom D, Olson K, Vallee B (1987) Isolation of angiogenin from normal human plasma. Biochemistry 26:5141-5146

55. Shapiro R, Vallee B (1989) Site-directed mutagenesis of histidine-13 and histidine-114 of human angiogenin. Alanine derivatives inhibit angiogenin-induced angiogenesis. Biochemistry 28:7401-7408

56. Sjöblom B, Salmazo A, Djinovic-Carugo K (2008) $\alpha$-actinin structure and regulation. Cell Mol Life Sci 65:2688-2701

57. Sreedharan J, Blair I, Tripathi V et al (2008) TDP-43 mutations in familial and sporadic amyotrophic lateral sclerosis. Science 319:1668-1672

58. Subramanian V, Feng Y (2007) A new role for angiogenin in neurite growth and pathfinding: implications for amyotrophic lateral sclerosis. Hum Mol Genet 16:1445-1453

59. Tsuji T, Sun Y, Kishimoto K et al (2005) Angiogenin is translocated to the nucleus of HeLa cells and is involved in ribosomal RNA transcription and cell proliferation. Cancer Res 65:1352-1360

60. Van Deerlin V, Leverenz J, Bekris L et al (2008) TARDBP mutations in amyotrophic lateral sclerosis with TDP-43 neuropathology: a genetic and histopathological analysis. Lancet Neurol 7:409-416

61. Vance C, Rogelj B, Hortobagyi T et al (2009) Mutations in FUS, an RNA processing protein, cause familial amyotrophic lateral sclerosis type 6. Science 323:1208-1211

62. Vandekerckhove J, Weber K (1978) At least six different actins are expressed in a higher mammal: an analysis based on the amino acid sequence of the amino-terminal tryptic peptide. J Mol Biol 126:783-802

63. Weiner H, Weiner L, Swain J (1987) Tissue distribution and developmental expression of the messenger RNA encoding angiogenin. Science 237:280-282

64. $\mathrm{Wu} \mathrm{D,} \mathrm{Yu} \mathrm{W,} \mathrm{Kishikawa} \mathrm{H}$ et al (2007) Angiogenin loss-of-function mutations in amyotrophic lateral sclerosis. Ann Neurol 62:609-617

65. Wyszynski M, Lin J, Rao A et al (1997) Competitive binding of $\alpha$-actinin and calmodulin to the NMDA receptor. Nature 385:439-442

66. Yamasaki S, Ivanov P, Hu G, Anderson P (2009) Angiogenin cleaves tRNA and promotes stress-induced translational repression. J Cell Biol

67. Yang Y, Hentati A, Deng H-X et al (2001) The gene encoding alsin, a protein with three guanine-nucleotide exchange factor domains, is mutated in a form of recessive amyotrophic lateral sclerosis. Nat Genet 29:160-165

68. Yokoseki A, Shiga A, Tan C et al (2008) TDP-43 mutation in familial amyotrophic lateral sclerosis. Ann Neurol 63:538-542 